\title{
Effects of excessive weather on the micro-climate of apple plantations under the hail protection nets
}

\author{
Lakatos, L. 1, Gonda, I. ${ }^{1}$, Soltész, M. ${ }^{2}$, Szabó, Z. ${ }^{1}$, Szél, J. ${ }^{1}$ \& Nyéki, J. ${ }^{1}$ \\ ${ }^{1}$ University of Debrecen Centre for Agricultural and Aplied Economic Sciences, \\ H-4032 Debrecen, Böszörményi u. 138., Hungary \\ ${ }^{2}$ Collage of Kecskemét Faculty of Horticulture, H-600 Kecskemét, Erdei Ferenc tér 1-3
}

\begin{abstract}
Summary: The general utilisation of hail nets is spreading all over the world and in Hungary too. Hail nets are at present the only tool, which is able to prevent heavy hail damage in agricultural crops. Besides its numerous advantages, there are also deleterious side effects, e.g. it changes the microclimate of the crop stand. Our study aimed to observe the differences, which characterise the physical status of crop stands under the protection of hail nets compared with the stands in open air under various meteorological conditions: high or low temperature, calm or windy atmosphere and their possible combinations. The results indicated that on hot and calm days the difference may attain $3-4^{\circ} \mathrm{C}$. On cool summer days, the difference was only $1.5^{\circ} \mathrm{C}$. The hail net influences the relative humidity of the air, which means on ho summer days often 7-8\% differences. Conditions of radiation may also differ conspicuously. Measurements prove the reduced global radiation on sunny summer days to $70 \%$. This impairs as a rule the development of fruits reducing their quality and also its quantitative traits. Sunburn is, on the other hand, significantly prevented by shadow.
\end{abstract}

Key words: hail nets, microclimate, apple growing, relative air humidity

\section{Materials and methods}

At present, fruit growing farms using hail nets are still few in Hungary. Costs of investment are expensive. Knowledge and experiences concerning the use of hail nets are still scarce. In the literature there are numerous publications dealing with the object, especially on the question of the preferred colour of the plastic net, which is decisive which spectral regions are transmitted or sorted out: Castellano et al. (2008) Hemming et al.(2008) under the net. It was stated that the black colour secure high constancy to the composition. Al-Helal and Abdel-Ghany (2010) explain that the colour, porosity and mesh density influence the photosynthetic intensity. They stated that less than $150 \mathrm{~W} / \mathrm{m}^{2}$ PAR is sufficient to normal growth of plants. Numerous papers dealt with the possibility to promote photosynthetic efficiency by mulching, when the mulched or specially covered surface reverberate the light Solomakhin and Blanke (2007), Blanke M.M. (2008). Recently, research was concentrated to the examination of effects exerted on the quality, i.e. development of anthocyanines as covering colours of fruits (Jakopic et al. (2007), Romo-Chacon et al. (2007)

The modified microclimate was explored by Hunsche et al. (2010). They stated that black nets diminished light intensity by $6-10 \%$ and increased the relative humidity, which does not cause concern until normal phytosanitary measures are observed.
The present study aimed to communicate the knowledge accumulated on the topic of using hail nets in the practice under various meteorological conditions comparing the parameters raised under and outside of the areas covered by the net. The locality of the experiments was the experimental orchard of the Debrecen University at Pallag. The hail net applied was black and had the form of a tent, its mesh size was $3 \times 9 \mathrm{~mm}$, the product of the Frustar enterprise. The apple variety was Early Gold volt, planted in 2003. Planting design was $3 \times 1 \mathrm{~m}$. Data characterising the microclimate were raised by an agrometeorological station of HWI type.

\section{Results}

Data were registered in a period between June 1 and September 30 2011. Special attention was paid during the summer on extreme meteorological happenings, when the difference between covered and free spaces was especially interesting. Differences in temperature were registered by Platina resistance sensors placed into the canopy of trees. Three sensors are mounted on a tree: on the Northern, Southern and Central part of the crown, in each case, the sensors are fixed on the lower surface of the branches in order to avoid the effect of direct radiation. The mean of the three data represented the temperature of the canopy. On hot days when the temperature exceeded $30^{\circ} \mathrm{C}$, the changes are followed across the whole day parallel outside and inside the 
net. It turned out that under the net the canopy was cooler during early afternoon by $3.5^{\circ} \mathrm{C}$, than outside. During night time, the temperature was higher by $2.5-3^{\circ} \mathrm{C}$. It is explained with the braking effect of the net on the radiation of heat rays of long wave length. Cooling down as well as the warming up under the hail net is delayed. That means, the risk of heat stress is highly prevented by the net. However, effects on the quality are less favourable: development of the colour and sugar accumulation.

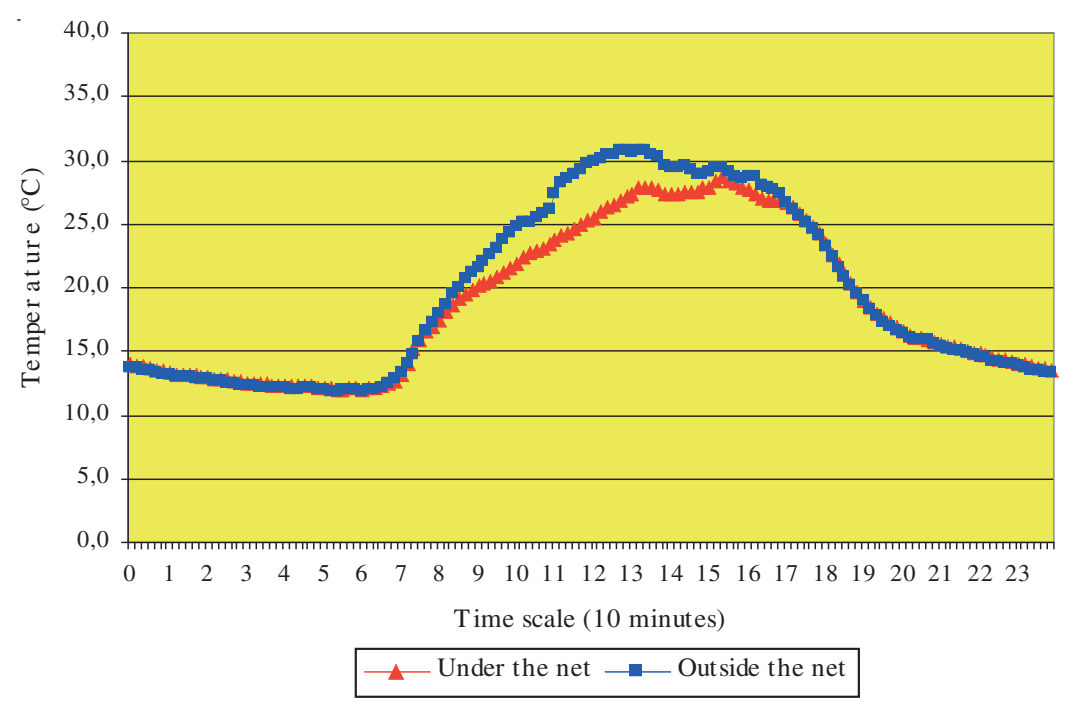

Figure 1. The mean daily course of temperature under the hail protection net and outside of it /Pallag 2011 June 1 - September 30/

Results show that the temperature under the hail net used to be lower than outside during the morning hours, which may attain $4-5^{\circ} \mathrm{C}$ at noon. (Figure 1). After noon, the difference between inside and outside temperatures diminishes quickly. During night, it is warmer inside by $0.5-1{ }^{\circ} \mathrm{C}$. The diffuse, reverberated radiation with long wave length is dominant. As a consequence, the difference is the opposite sense. From the point of view of quality, the delayed accumulation of sugars and the development of the skin colour, the effect may regarded as less favourable.

Variation of temperature had a mean amplitude between 19 and $22{ }^{\circ} \mathrm{C}$ during the period of measurements (Table 1). Under the hail net, the amplitude was smaller by $2-3{ }^{\circ} \mathrm{C}$ than outside. During days with marked variation of temperature,

Table 1. The statistical parameters of daily amplitude of temperature changes measured under the hail protection net and outside of it /Pallag 2011 June 1 - September 30/

\begin{tabular}{|l|c|c|}
\hline & Temperature $_{\text {outside }}$ & Temperature $_{\text {under the net }}$ \\
\hline mean & 21.8 & 19.1 \\
\hline SDeviaton & 4.9 & 4.4 \\
\hline CV & 22.3 & 23.0 \\
\hline $\max$ & 29 & 24.7 \\
\hline $\min$ & 5.6 & 4.6 \\
\hline
\end{tabular}

the amplitude was larger by $4{ }^{\circ} \mathrm{C}$ outside than inside the hail net.

Attention was concentrated to days, which excelled by large variation of temperature, when the radiation promised intense accumulation of sugars and cover colour if the skin. The amplitude between the two environments culminated around $7-8{ }^{\circ} \mathrm{C}$ at noon (Figure 2).

On cool, cloudy days, when the maxima were lower than $25^{\circ} \mathrm{C}$, the mean difference between outside and inside did not attain $0.5^{\circ} \mathrm{C}$. At that time, inside the net, the leaves were warmer than outside the net. The shadow effect was minor compared with the effect of dispersed radiation with long wavelength and the radiation to the opposite direction. Consequently, the temperature was higher inside than outside the net. The difference was less than $0.2-0.5^{\circ} \mathrm{C}$. In the morning and evening there was little difference of temperature between the two sides of the net (Figure 3).

Considering the relative air humidity, the following statements are forwarded:

Beginning with the hours of late morning until the early afternoon the air humidity was higher under the net by $7-8 \%$ than outside. The sense of the difference was maintained throughout the night, but was smaller, 3-3\% (Figure 4).

Under the hail net, the variation of relative air humidity varied with an amplitude less than $2 \%$ (Table 2). In spite of that, the variance of the mean relative air humidity (CV\%) was higher by $7 \%$ than outside the net.

Table 2. The statistical parameters of daily amplitude of relative air humidity measured under the hail protection net and outside of it /Pallag 2011 June 1 - September 30/

\begin{tabular}{|l|c|c|}
\hline & $\mathrm{RN}_{\text {outside the net }}$ & $\mathrm{RN}_{\text {under the net }}$ \\
\hline mean & 56.2 & 53.9 \\
\hline SDeviation & 10.1 & 12.6 \\
\hline $\mathrm{CV}$ & 18.0 & 23.4 \\
\hline $\max$ & 69.6 & 70.2 \\
\hline $\min$ & 14.7 & 13.3 \\
\hline
\end{tabular}

On hot days, when the amplitude of the variation of humidity attained $60 \%$, the differences between the two sides of the net was $15-16 \%$, at night 6-7\%, the inside having always the higher values (Figure 5). On hot days with maxima more than $30^{\circ} \mathrm{C}$, the minimum humidity declined until $30-40 \%$ in the early afternoon. This is really a drought, which ought to be counteracted by using micro-sprinklers. This minimum is always moderated inside the hail net. As a rule, the minimum of relative air humidity is not less than 45 $-55 \%$. This is an important advantage of the net. On the other 


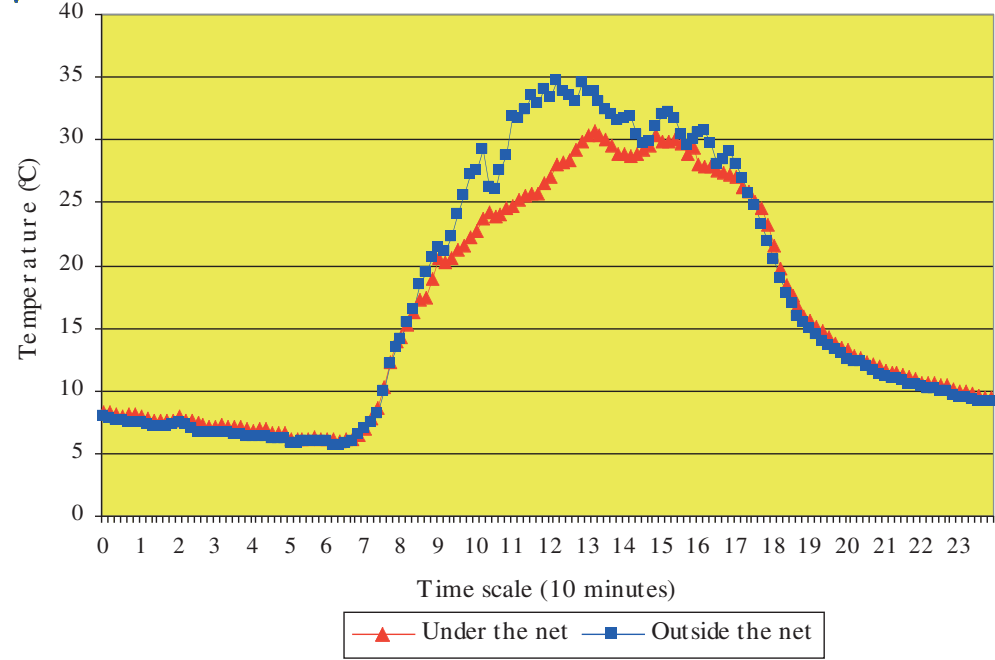

Figure 2. The mean daily course of temperature under the hail protection net and outside of it on especially hot (variable) days $\left(\mathrm{T}_{\text {diff }}>25^{\circ} \mathrm{C}\right) /$ Pallag 2011 June 1 - September 30/

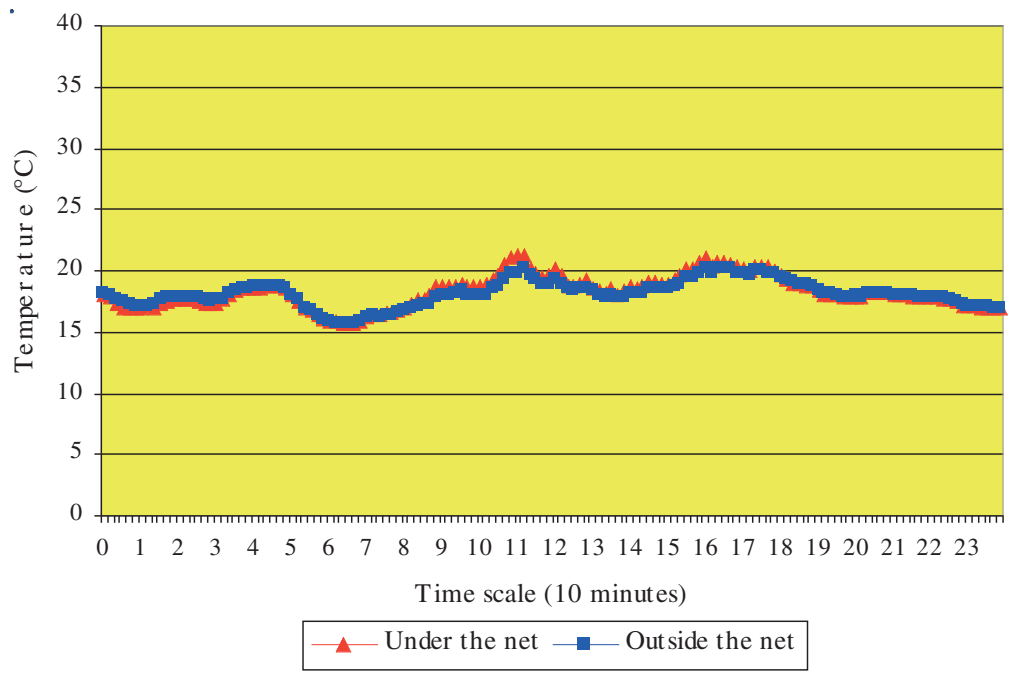

Figure 3. The mean daily course of temperature under the hail protection net and outside of it on especially calm days with little variation of temperature $\left(\mathrm{T}_{\text {diff }}<10^{\circ} \mathrm{C}\right) /$ Pallag 2011 June 1 September 30/

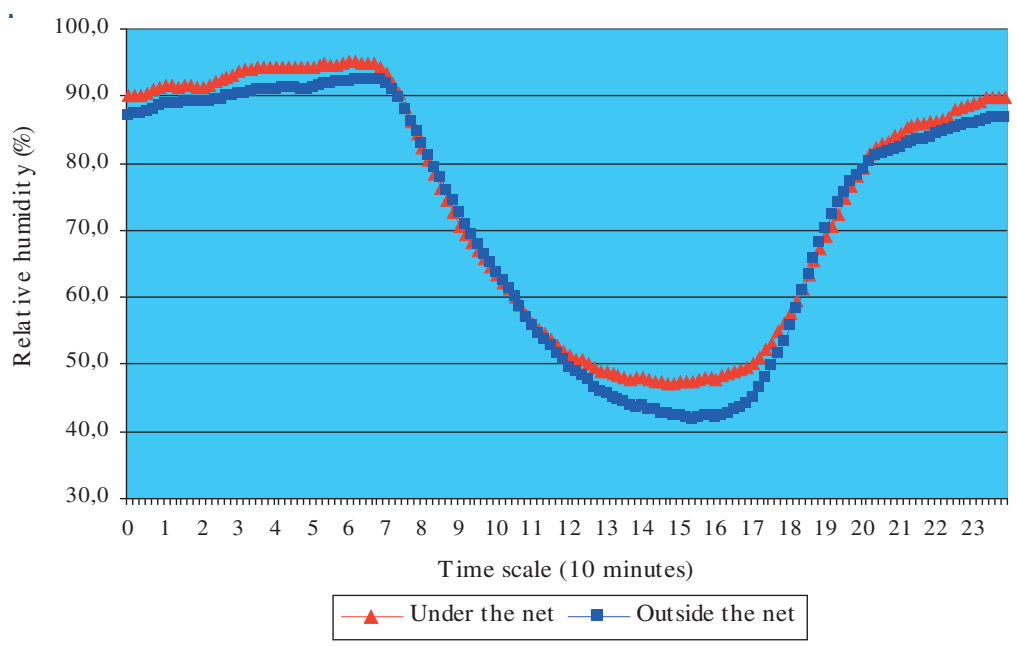

Figure 4. The mean daily course of the relative air humidity measured under the hail net and outside of it /Pallag 2011 June 1 - September 30./ hand, the higher humidity may favour the appearance of bacteria and viruses. But the retention of the humidity improves the water balance of the trees. Around the hours of morning and late afternoon marked differences develop in air humidity and dwindle in the early afternoon and evening hours (Figure 5).

On cool, cloudy days, when the amplitude of humidity differences are less than $20 \%$, and the daily minima are still higher than $80 \%$, there are little differences between the both sides of hail net. The largest differences may vary between 2 and $35 \%$ humidity. During the night and morning hours, the differences in humidity used to be less than $1 \%$ (Figure 6).

The main objection of growers is perhaps the effect of hail nets as cause of shadow. i.e. reduction of light energy. All interference influencing light intensity affects photosynthesis as well as respiration of the plant stand. In our experiment, the black hail net was the object of study. Measurements of light intensity were performed during bright as well as cloudy summer days considering the different regions of the tree crowns. During the period of measurements, the global radiation at noon attained $500 \mathrm{~W} / \mathrm{m}^{2}$ outside the net. In morning and before noon, there were little differences between the outer and inner regions of the tree crown. The values of radiation measured inside and outside the hail net were almost the same (Figure 7), whereas at noon the differences approached 35-40\%.

Outside the net, the amplitudes of the varying values of radiation are larger by $15 \%$ than under the net (Table 3).

Table 3. The statistical parameters of daily amplitude of global radiation measured under the hail protection net and outside of it

/Pallag 2011 June 1 - September 30/

\begin{tabular}{|l|c|c|}
\hline & $\mathrm{RN}_{\text {outside the net }}$ & $\mathrm{RN}_{\text {under the net }}$ \\
\hline mean & 586.3 & 505.0 \\
\hline SDeviation & 144.2 & 130.2 \\
\hline $\mathrm{CV}$ & 24.6 & 25.8 \\
\hline $\max$ & 783 & 692 \\
\hline $\min$ & 76 & 47 \\
\hline
\end{tabular}

On sunny days, at noon, the radiation may culminate around $800 \mathrm{~W} / \mathrm{m}^{2}$ but under the hail net $640 \mathrm{~W} / \mathrm{m}^{2}$ is expected, i.e. $70 \%$, moreover, the differences between the outer and inner parts of the crowns $15-20 \%$ differences occur, which was not a matter to be studied yet. The reduction of 


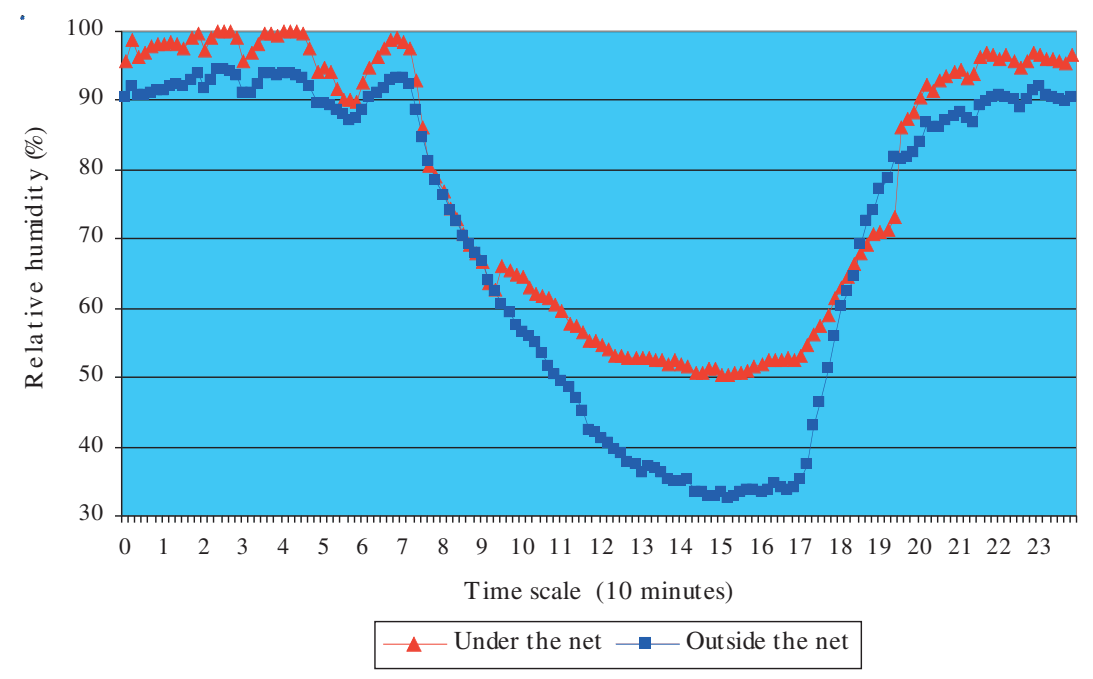

Figure 5. The mean daily course of the relative air humidity measured under the hail net and outside of it on a particularly day with high variation of air humidity $\left(\mathrm{RN}_{\mathrm{dif}}>60 \%\right) / \mathrm{Pallag} 2011$ June 1 - September 30./

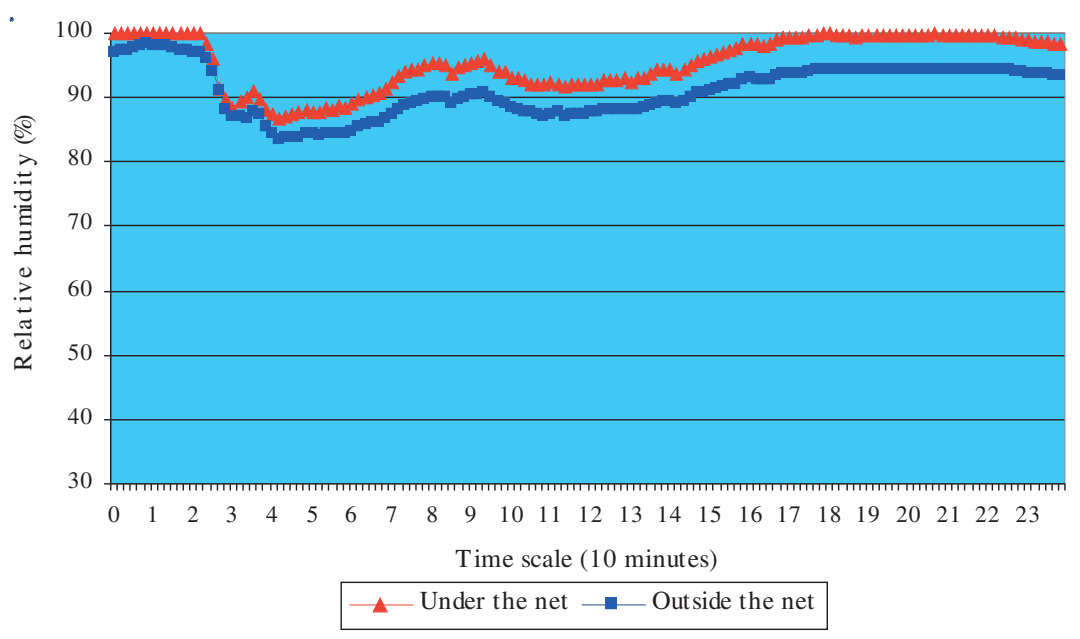

Figure 6. The mean daily course of the relative air humidity measured under the hail net and outside of it on a particularly calm day $\left(\mathrm{RN}_{\mathrm{dif}}<20 \%\right)$ /Pallag 2011 June 1 - September 30./

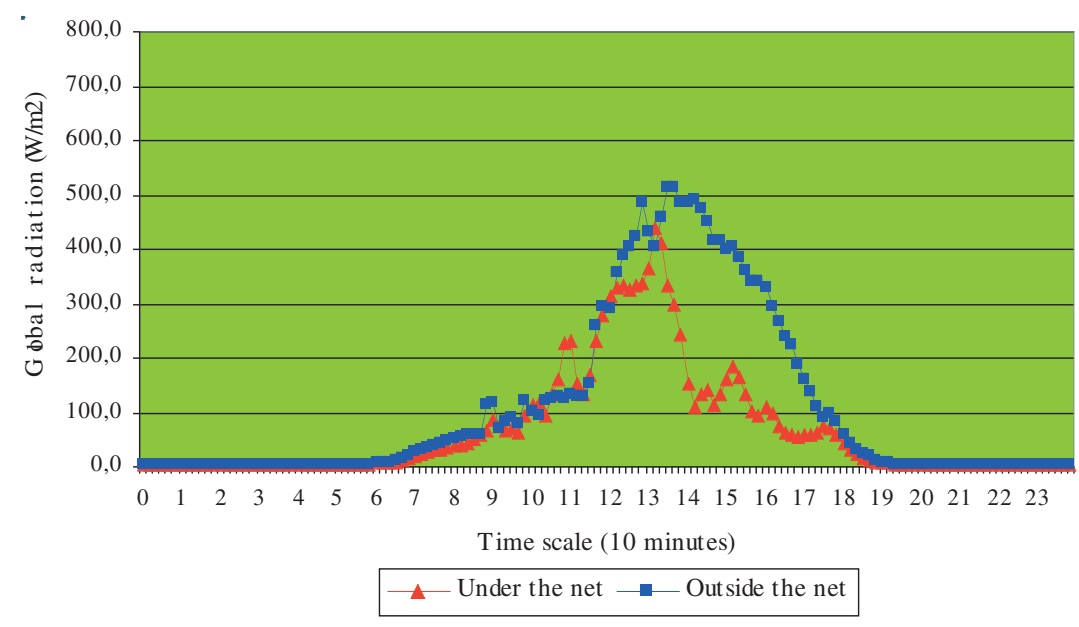

Figure 7. The mean daily course of global radiation measured under the hail net and outside of it /Pallag 2011 June 1 - September 30./ radiation by the hail net is most evident during noon time. At morning and late afternoon the reduction is only $5-10 \%$ (Figure 8).

In cloudy summer days, at noon, global radiation was on the surface of crowns less than $100 \mathrm{~W} / \mathrm{m}^{2}$. In that case, differences between inside and outside of the hail nets was not important. During late morning and late afternoon, there was a short period, when inside the hail net somewhat higher radiation has been measured than outside. The low position of the sun and reflections of rays may cause relatively slightly higher values of radiation inside the hail net than outside of it (Figure 9). The difference is otherwise around noontime less than 5\%, being higher outside.

Wind velocity influences the exchange of atmosphere. Intense wind eliminates the vertical differences of the profile of meteorological parameters. Calm weather or low velocity cause significant changes in vertical and horizontal microclimatic parameters.

Hail net modifies the effect of wind velocity. Measurements justify two categories: calm or low intensity, when maximum velocity is less than $3 \mathrm{~m} /$ second, versus velocity above $3 \mathrm{~m} / \mathrm{s}$. In low velocity days, the hail net reduces air movement at a rate of $50-60 \%$. If outside the net, wind blows with $1-1.5 \mathrm{~m} / \mathrm{s}$ velocity, inside $0.4-0.6 \mathrm{~m} / \mathrm{s}$ has been measured. At 0.5 $\mathrm{m} / \mathrm{s}$, the effect is even more accentuated, i.e. up to $90 \%$ (Figure 7).

In highly windy days, at high velocities, the differences between outside and inside space differences are growing unimportant. In late morning and late afternoon, velocities below $2 \mathrm{~m} / \mathrm{s}$, hail net modifies the velocity by 15-20\% (Figure 8). At low wind velocities, the modifying effect of the net is decisive, but above $2.5 \mathrm{~m} / \mathrm{s}$, the differences between outside and inside space is getting unimportant. Relative humidity of the atmosphere is higher at low velocities, and risks of pathological infections increase. Another important moment is the necessity of installing hail nets after blooming of trees only. Insect pollination, also wind pollination is negatively influenced by hail net. Practically, nets are mounted after bloom, thus phytosanitary moments remain to be considered only. Distribution of antiparasitic spray is more advantageous under lower wind velocities, i.e. hail nets increase the efficiency of spays. 


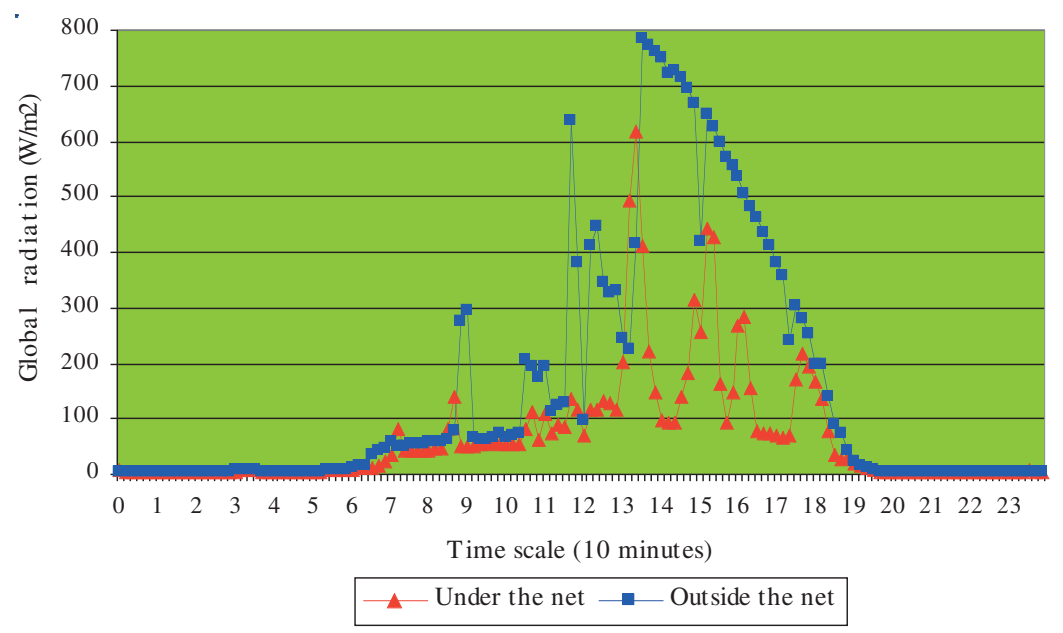

Figure 8. The mean daily course of global radiation under the hail net and outside of it on sunny days /Pallag 2011 June 1 - September 30/

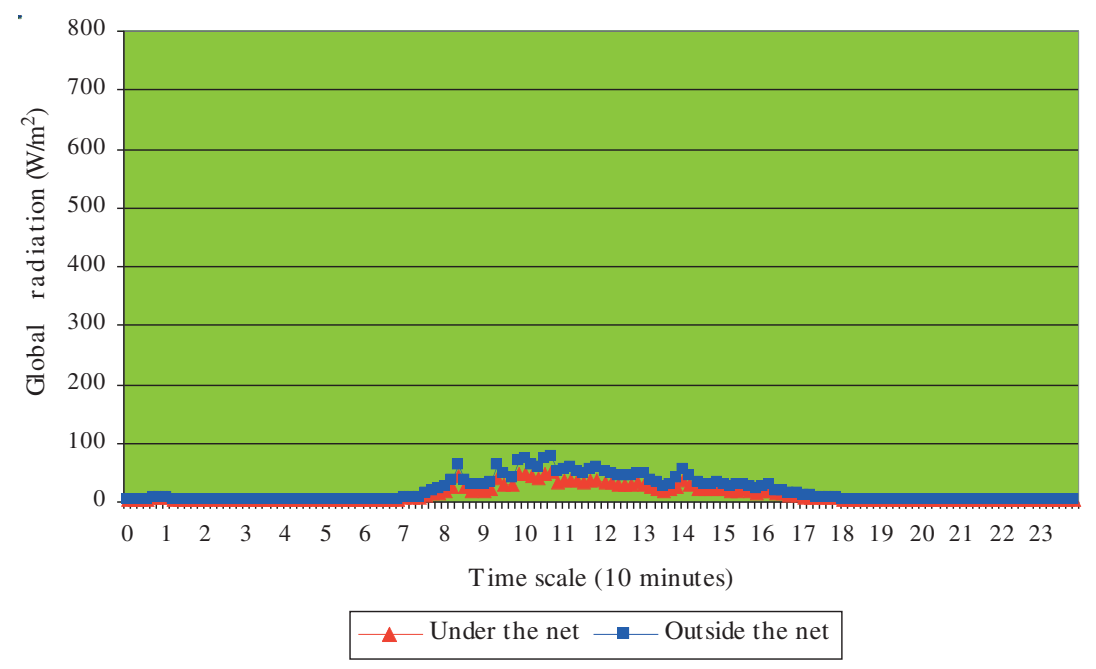

Figure 9. The mean daily course of global radiation under the hail net and outside of it on cloudy days /Pallag 2011 June 1 - September 30/

\section{Conclusions}

Advantages of the use of hail nets are coupled with some disadvantages too. Our study stated that microclimate of the orchard is modified markedly by hail net. Maxima of temperature are significantly lowered at low wind velocities on bright, sunny days. The influence of hail nets on the qualitative properties of fruits needs further inquiries. As far as hail nets lower the morning minima of the temperature as well as the daily maxima, they may impair the quality of fruits. Weak colour development, lower sugar content, disturbed relations of sugar and acids lower the marketing value of products. However, risks of sunburn are eliminated let alone the real aim of hail nets, i.e. avoid hail damage. It is worth while to choose the right variety for that purpose. They should develop the favourable covering colour under modified light and temperature, in addition to better tolerance to pathogens, fungi and bacteria.

\section{Acknowledgements}

This work was sponsored by NFÜ TECH 08-A4/2-2008-0138 grant.

\section{References}

Al-Helal, I.M. \& Abdel-Ghany A.M. (2010): Responses of plastic shading nets to global and diffuse PAR transfer: Optical properties and evaluation JAS - Wageningen Journal of Life Sciences Volume 57: 125-132.

Blanke, M.M. (2008): Alternatives to reflective mulch cloth $\left(\right.$ Extenday $^{\mathrm{TM}}$ ) for apple under hail net? Scientia Horticulturae, 116: 223-226

Castellano, S., Hemming, S. \& Russo, G, (2008): The influence of color on radiometric performances of agricultural nets Acta Hortic. 801: 227-236.

Hemming, S., Swinkels, G.L.A.M., Castellano, S., Russo, G. \& Scarascia, G.M., (2008): Numerical model to estimate the radiometric performance of net covered structures (AGRONETS), Paper presented at AgEng2008 Agricultural and Biosystems Engineering for a Sustainable World, Crete, 23-25.

Hunsche, M., Blanke, M. \& Noga, G. ( 2010): Does the microclimate under hail nets influence micromorphological characteristics of apple leaves and cuticles? Journal of Plant Physiology

167: 974-980.

Jakopic, J., Veberic, R. \& Stampar, F. (2007): The effect of reflective foil and hail nets on the lighting, color and anthocyanins of 'Fuji' apple Scientia Horticulturae 115, (1): 40-46.

Romo-Chacon, A., Orozco-Avitia, J.A., Gardea, A.A., GuerreroPrieto, V. \& Soto-Parra, J.M. (2007): Hail Net Effect on Photosynthetic Rate and Fruit Color Development of 'Starkrimson' Apple Trees Hail Net Effect on Photosynthetic Rate and Fruit Color Development of 'Starkrimson' Apple Trees. Jurnal of the American Pomological Society 61 (4): 174-178.

Solomakhin, A.A. \& Blanke, M.M., (2007): Overcoming adverse effects of hail nets on fruit quality in apple orchards by reflective cloth (Extenday ${ }^{\mathrm{TM}}$ ), J. Sci. Food Agric. 87 (14) 